\title{
The genesis of the College of Optics and Photonics at the University of Central Florida
}

\section{J. Soileau}

M. J. Soileau, "The genesis of the College of Optics and Photonics at the University of Central Florida," Proc. SPIE 9664, Ninth International Topical Meeting on Education and Training in Optics and Photonics, 96642B (24 October 2005); doi: 10.1117/12.2207757

SPIE Event: Ninth International Topical Meeting on Education and Training in Optics and Photonics, 2005, Marseille, France 


\title{
Ref ETOP075
}

\section{The Genesis of the College of Optics and Photonics at the}

\author{
University of Central Florida (UCF)
}

\author{
M.J. Soileau
}

\begin{abstract}
Optics has emerged as a major "topic" in modern science and engineering. In fact, optics is playing an ever more important role in the world's economy and in medicine, as well as in military systems. However, in most academic institutions, optics (or any of its more contemporary names, such as photonics, quantum electronics, electro-optics, laser science, etc.) is confined to a course or two within the more "traditional" disciplines of physical science and engineering. In the language of mathematics, optics has not been considered as one of the base vectors (i.e., disciplines) used to define academic institutions. A notable exception is the emergence of the first college at an American University, the College of Optics and Photonics at UCF, devoted to optical science and engineering. The evolution of the academic research center CREOL (initially the Center for Research in Electro-Optics and Lasers) into a center devoted to research and education, to a School of Optics, and now the College of Optics and Photonics, will be reviewed.
\end{abstract}

\section{Early History: FTU to UCF}

\section{Summary}

The story of the College of Optics and Photonics begins with the establishment of Florida Technological University (FTU) in Orlando, Florida in 1968. FTU was founded in response to the increasing population in Central Florida (a triangular region with the cities of Orlando, Daytona Beach, and Melbourne at its points) and the emergence of technology-based industries in the aero-space economic sector.

The initial magnet that attracted high-tech industries was the establishment of America's Space Port at Cape Canaveral (about $75 \mathrm{~km}$ east of Orlando and the location of the aerospace giant Martin Marietta, approximately $25 \mathrm{~km}$ to the south of the center of Orlando. The subsequent growth of America's space program fueled the need for a scientific and engineering workforce to support what would become the Kennedy Space Center (KSC). Pressure from the community and business interests resulted in the Florida Legislature establishing FTU as primarily an engineering school and locating it in East Orlando (20km from the center), approximately midway between the Martin Marietta facility and Cape Canaveral.

FTU was established to meet community needs for an educated workforce. This fundamental idea of integration of the university into the economic fabric of the Central Florida region is the guiding principle behind the university's growth and development and continues to guide the university's development to this day.

The next critical event in the Central Florida region was the decision by Walt Disney to establish a major "theme park" or tourist center, Disney World, near the Martin Marietta facility. This sparked the explosive growth of the population of the region, which continues today. The large influx of new arrivals was not the elderly retired people witnessed in other parts of Florida. Rather, large numbers of young families began to arrive in large numbers. 
This growth, in turn, fueled the need for access to higher education for these new citizens. This need included not only engineering, but also business, the social and physical sciences, education, and all the professions associated with a rapidly growing community. Thus, the mission of FTU expanded beyond engineering and the university's name was changed in 1978 to the University of Central Florida (UCF) to reflect this broader mission.

Today UCF is the 8th largest university in the United States, with an enrollment of over 45,000 students. The university self-identifies itself as a "Metropolitan Research University". This is defined to mean that the university endeavors to weave itself into the economic, cultural, and social fabric of the region, in which it is located.

\section{From Reactive to Proactive}

UCF (FTU in the beginning) was formed in reaction to the needs of the aerospace industry and the NASA Kennedy Space Center (KSC) at Cape Canaveral. By the mid-1980s Central Florida had evolved into a major tourist destination. The primary components of Florida's economy were tourism, agriculture (primarily citrus), building (associated with the large increase in population) and technology-based industry, a distant fourth. By far the fastest growing sector was tourism, which is dominated by low wage service jobs.

In the mid-1980s Florida's Governor, Bob Graham, recognized that the state's economy was becoming more and more one-dimensional in its dependence on low-wage service jobs. He formed a group called the Florida High Technology and Industry Council (FHTIC), made up of industry and business leaders to identify ways to boost Florida's technology-based, wealth-producing industry.

The FHTIC produced two major recommendations:

Establish a source of funds for competitive applied research programs at the states' universities to be conducted in partnership with the state's tech-based industry.

Establish research centers at the states' universities to add research infrastructure and expertise in key areas to support existing and emerging tech-based industry. These centers were meant to be placed near the industrial centers in the state. Lightwave technology (optics) was identified as a key industry sector for concentration by the FHTIC, and that group recommended that the state should "form CREOL (then called the Center for Research in Electro-Optics and Lasers) to provide Florida's high-tech industries with access to research students and faculty in advanced areas of optical and laser sciences."

Recommendation (1), the applied research program, was funded by the Florida Legislature in 1985. A project was established to address all aspects of diode-pumped lasers. The University of South Florida (Tampa) was tasked with growing single crystal fiber laser sources, the University of Florida (Gainesville) was tasked to develop laser diodes, and UCF was tasked to do the "system," i.e. all aspects of laser design and integration. The lead scientist at UCF, Professor Ronald Philips used the resources allocated to UCF to fund CREOL and a variety of projects, most of which were only partly related to the diodepumping project. This caused a few problems (particularly with the industry group tasked with oversight), however, CREOL was born!

\section{Formal Approval of CREOL}

The 1986 Florida Legislature appropriated $\$ 1.5 \mathrm{MM}$ of recurring funds for the UCF budget to support CREOL. 
A key factor in the evolution of the College of Optics and Photonics was this commitment of recurring funds that allowed new tenure-earning and tenured faculty to be hired. A stable base of institutional support is absolutely essential for the long-term success of any academic enterprise.

A second key factor was that the legislative appropriation came to the university as "block" or "line-item" funds not connected to enrollment of the university and the student credit hours generated from the courses taught by the faculty. This allowed the faculty positions established through the CREOL funds to be structured so as to allow faculty to develop internationally competitive research programs.

To understand the significance of the latter point, one must realize that UCF considered itself primarily a "teaching" institution. Faculty teaching assignments were two- to three-times that of the top state supported universities (such as the University of California System) in the United States. If CREOL were to have any chance to accomplish its legislative mandate, then it was essential that the work environment and assignments be competitive with the best of the United States' universities.

\section{Some Dark Days}

The author arrived at UCF on January 2, 1987, as the first Director of CREOL. On that very day advertisements were written to recruit faculty and students.

The second order of business was to examine the budget and laboratory facilities for the yetto-be-hired faculty. The CREOL funds had been dispersed to a variety of university departments to fund self-described "CREOL research projects" and CREOL had been allocated a suite of three offices and a doublewide mobile home for laboratory space!

The grand plan to "kick start" CREOL was to move a fairly successful research group (Eric Van Stryland, Dave Hagan, the author, and seven graduate students) en masse from the University of North Texas to UCF. The doublewide just would not accommodate the people or the 42,000 pounds of optics tables and other equipment to be moved...much less the additional 13 faculty to be hired. On the other hand, the additional 13 faculty would not be an issue if the CREOL budget could not be re-captured.

Thus began some really dark days for the Director: a new center that had no space and whose budget had diffused out to other worthy causes. The Director's wife and children were back in Texas. His colleagues, students, and laboratory equipment was in Texas as well. The administration was at war with the Director it had just hired. The industry leaders, the legislature, the senior university leadership, and the Director were all focused upon a new unit that would bring new faculty to the University. However, many of the existing faculty, department chairs, and deans saw CREOL as a source of funds to relieve their funding shortages that characterized the rapidly growing university. Efforts to regain control of the CREOL budget resulted in a request by a group of department chairs to the UCF Provost to remove the Director.

The continued encouragement of my colleague Professor Ron Phillips, the support of the UCF Provost (Dr. Richard Astro), the support of business leaders from Florida optics companies (most notably the late Dr. Bill Schwartz of Schwartz Electro-Optics), and the still present opportunity to build an academic unit devoted to optics somehow all helped CREOL to "stay the course" in those early months. 


\section{"The Texans"}

The next problem was to "ransom" our equipment from the University of North Texas (a story in itself!). Somehow problems were solved and on a nice Saturday in April 1987, a Texas caravan arrived with two moving vans full of optics tables and lasers, seven graduate students, Dave Hagan (presently Associate Dean of the College of Optics and Photonics), and Eric Van Stryland (presently Dean of the College of Optics and Photonics/CREOL and President-Elect of the Optical Society of America).

The arrival of the "Texans" was critical to the success of CREOL. UCF was a fledgling university -- first graduates were in June 1970 -- with little expertise in leading edge research or graduate programs. The "Texans" brought competitively funded research projects, fulltime graduate students, and fully equipped laboratories. At CLEO in May 1987, there were many papers from our new organization, and the fledgling staff of CREOL was working the halls and receptions at CLEO to recruit more faculty.

The good news was that the "Texans" allowed CREOL to show instant success. The bad news was that they had consumed all the laboratory space that could be begged, borrowed, or stolen from other units on campus, and nobody was in the mood to provide more. Furthermore, it was realized that no matter how much blood was spilled, there was simply not enough space available on the campus that had 16,000 students enrolled and was growing to over 45,000 in the Fall of 2005 . The solution to this dilemma was to move CREOL to rental space in the Central Florida Research Park -- adjacent to the main UCF campus. By the summer of 1987, build-out of laboratory space for CREOL in the Research Pavilion was underway. During the Christmas-New Year holiday of 1987, CREOL's "Texans" moved again. If nothing else, CREOL faculty and students would be experts in moving optics tables!

The move off campus had many drawbacks. Among these was the lack of chaos of a university and the opportunity for casual contact with faculty from different disciplines. However, in retrospect, exile was probably a good thing. As previously mentioned, the "lineitem funding" of CREOL allowed us to structure faculty duties consistent with those at toptiered universities. This caused much resentment among colleagues outside of CREOL. Being out of sight helped to diffuse the issue. Once the space problem was adequately addressed, CREOL turned its focus to the hiring of faculty, the recruitment of students, and the development of graduate curricula in optics.

\section{Hiring of CREOL faculty}

CREOL reported to the Vice President for Research. There was no provision for the granting of tenure in the Center. Faculty were to be hired with CREOL funds and positions with tenure, or tenure track, decisions had to be made in one of the traditional academic units. The plan was to recruit faculty in optics and present them for approval in specific units. The traditional units -- physics, electrical engineering, etc. -- said, "No, give us the positions, we will recruit, and you can elect to accept or reject those faculty, which we decide to hire." Much of the gray in the author's beard stems from this great debate! The view that CREOL should recruit its faculty prevailed, but the debate was re-kindled every time a new department chair or dean was hired. Part of the problem was that some of our faculty recruits just did not "fit" into any of the UCF departments, e.g., faculty with Ph.D's in geology, nuclear engineering, and optical science. This was one issue, which was never totally resolved until the School of Optics was formed in 1998. However, we did arrive at a workable, simple 25-step hiring process that allowed us to proceed. 


\section{Growth Years}

And proceed we did! Table 1 shows the chronological ordering of the hiring of CREOL faculty. We fanned out to all the major optics-related conferences and worked the employment centers and the networks of colleagues.

In the early days, we had few top applicants from junior faculty. In addition, we realized that senior faculty brought their reputations, students, and equipment (sometimes) with them. We had a broad plan to hire in various areas of optics to give the proper breadth to our education program. In the end, most of the early hiring was determined by what I call targets of opportunity. We would pick up vibes that a person was at least thinking of leaving his or her institution. We would then invite the person to visit and give a seminar. If we liked what we saw, then we put on the pressure for them to formally apply. We wined and dined the candidates. I took them on boat trips to see Florida wildlife. (Ask Pete Delfyett to tell you about our alligator-stalking trip or Alan Miller about being caught in a large thunderstorm in a canoe!)

We landed some candidates and some got away. Either way, we spread the word that we existed, that we were doing good work, and that we were hiring.

\section{Building a Sense of Community}

CREOL faculty were tenure-tracked in a number of departments and our optics course offerings and degree programs were offered through a variety of units. This made it important to do things that would build a sense of unity in the optics faculty and students. Among the things we did to build identity were:

- instituted self-governance, which included an Executive Committee to advise the Director, and annual peer appraisal of CREOL faculty.

- instituted student recognition, complete with a formal "Certificate of Appreciation" for all our graduates (until the school was formed the formal degrees were awarded by the university's traditional units).

- published a newsletter "CREOL Highlights" that is distributed internally and to the external community. (Any CREOL alumni out there not receiving Highlights, contact the College of Optics and Photonics to get on the list.)

- established a tradition of family gathering, i.e., the CREOL Spring Thing, held the Saturday following the spring SPIE Aerosense meeting in Orlando.

- encouraged the faculty to be active in professional society activities and the students to form student chapters (We have student chapters of OSA, SPIE, and LEOS, plus CAOS - the CREOL Association of Optics Students, which includes the members of all the student chapters.).

\section{Move Back to Campus}

December of 1995 found us once again using the holiday season to move optics tables, this time to our beautiful, 82,000-square-foot building located on the exact spot of the old doublewide trailer. By this time, the Center had grown to more than 150 students, staff, and faculty. We reckon we moved about an acre of optics tables! In January of 1996, the Board of Regents approved MS and Ph.Ds in Optical Science and Engineering.

\section{The School of Optics}

In the Spring of 1996, we convinced an external review panel (Art Guenther, University of New Mexico; Bob Shannon, University of Arizona; and Brian Thompson, University of Rochester) to review our progress, structure, plans, and programs. The key recommendation of this panel was that CREOL should be made into an academic unit with its own degree programs, tenure of its faculty, etc. That sparked an intense campus wide 
debate. The arguments for the establishment of the school were simple: 1. Optics has become a discipline unto itself; and 2 . The CREOL faculty recruited the students, taught the formal classes, secured the funding for the student stipends, supervised the students dissertations, and helped them in jobs upon graduation. Simply put, we were already doing all the functions of an academic unit, so why not give us that designation?

On February 18, 1998, Provost Gary Whitehouse, with the support of President John Hitt, announced the approval of the School of Optics, and on September 11, 1998, the Board of Regents gave its formal approval to the School. On January 11-12, 1999, the School of Optics Inaugural Conference was held and attended by many leaders from the optics community, including three Nobel Laureates. The author stepped down from the director's position on July 1, 1999, to become Vice President for Research at UCF.

Eric Van Stryland became Interim Director of the School of Optics/CREOL on July 1, 1999, and was named Director on July 1, 2000.

\section{The College of Optics and Photonics}

The School of Optics/CREOL soared to new heights under the leadership of Eric Van Stryland. In the Spring of 2002, Florida Governor Jeb Bush proposed a new initiative to establish Centers of Excellence at Florida's universities to help stimulate and grow Florida's tech-based economy. The legislature appropriated \$30MM (the governor had requested $\$ 100 \mathrm{MM})$ to establish three such centers.

This new initiative was identical to CREOL in its approach and goals. The School of Optics/CREOL proposed that the Florida Photonics Center of Excellence (FPCE) be established in the School of Optics. Sixteen proposals were submitted and Florida's Emerging Technology Commission ranked the FPCE proposal first, resulting in a one-time influx of $\$ 10 \mathrm{MM}$, of which $\$ 3 \mathrm{MM}$ was used to endow Eminent Scholar Chairs.

The optics faculty at UCF continued to produce outstanding accomplishments in research. Our students were highly sought after, particularly by industry. The optics enterprise at UCF had grown to a budget of approximately \$20MM /year.

However, problems remained. Among these was the fact that the School of Optics and its academic programs reported to the Vice President for Research (the position was then and is currently held by the author). This did not set well with the more traditional faculty and administrators at the university. UCF had grown to exceed 40,000 students but had the same administrative structure of five colleges that it had when it had been less than half this number of students.

Two other units had grown in size and complexity that strained the existing administrative structure. One of these, the Biomolecular Science Center, had been granted authority to award tenure, a structure very similar to that which served the Optical Science Center at the University of Arizona well for many decades, and that caused much controversy in the UCF Faculty Senate.

In this context the Director of the School was limited by the university personnel policies in hiring and promoting its staff. The title "Director" is very common throughout the university, e.g., Director of the University Book Store, etc. The title "Dean," on the other hand, comes with great authority and prestige at UCF. 
Provost Terry Hickey solved all these problems by announcing three new colleges:

- the Rosen College of Hospitality Management

- the Burnett College of Biomedical Science

- the College of Optics and Photonics.

These three new colleges report directly to the Provost.

The author had much detailed involvement in the development CREOL, the School of Optics, and UCF Optics degree program. However, he was not part of the decision to form the college, other than to lobby that Eric Van Stryland should be allowed to promote his administrative assistant to a position reserved for Dean's assistants.

Eric Van Stryland was named Dean of the new college and has led it to new heights of accomplishment and prominence. The new structure has brought new resources and opportunity for CREOL's faculty and students.

Most importantly, the new college has placed optics research and education in a more stable structure with a much louder voice. The new college can better interact with its peer colleges at UCF, and position the faculty to develop undergraduate degrees in optics, should they choose to do so.

The granting of optics the status of a college is important recognition that optics is one of the "basic vectors" that define a modern university. Without question, this signals the recognition that optics is, indeed, a discipline unto itself, rather than a subset of other fields.

\section{Faculty Accomplishments}

There are many things discussed that were key to the development of the College of Optics and Photonics. None of these are as important as the simple fact that our faculty have distinguished themselves among their peers world-wide. All of the tenured faculty are Fellows of the professional societies that serve the optics community and serve in positions of leadership in organizations such as SPIE, OSA, IEEE-LEOS, etc. Examples of outstanding accomplishments are too numerous to list but include seminal works that are among the top cited literature in optics in diverse areas such as: new optical characterizations techniques; fundamental advances in laser-matter interaction; new laser sources; display systems; imaging; integrated optics/photonics; ultra-fast spectroscopy; new optical materials; etc.

The previous discussions in this paper all speak to setting up the boundary conditions so that faculty can best pursue their scholarship and educate their students. However, what have been most significant in the evolution of the colleges are the specific accomplishments of our faculty, staff, and students. The world's scientific community, through its recognition via awards, citations of work, and participation in our programs, has confirmed our position among the top organizations in our discipline. The Florida business and political leadership has recognized our commitment to economic development by the award of the Florida Photonics Center of Excellence. New companies have been born from the intellectual capital developed at CREOL.

In summary, promises of excellence in scholarship, in the education of students, and the development of economic opportunity have been met by our faculty. Without such accomplishments, all arguments about administrative structure and academic disciplines are of no consequence. 


\section{The Future}

Of course, this chapter is yet to be written. There are now 26 faculty and about 150 graduate students in the College of Optics and Photonics. The faculty supervises students in the optics MS and Ph.D programs, as well as students in physics, electrical engineering, mechanical engineering, computer science, and other disciplines wanting to do a dissertation in optics. The faculty also offers undergraduate "minors" in optics through the department of physics. The College of Optics and Photonics/CREOL remains dedicated to its original mission of aiding the development of optics-based industry, by providing an educated workforce, research partnerships with industry, tech transfer - including spinning out new companies, and fundamental research that forms the base for future optics-based industry.

The future of the College of Optics and Photonics/CREOL is linked to the bright future for UCF. The idea that spawned CREOL - partnership with industry and the community - is central to the UCF culture. The university is making great progress in graduate education and research activities in many disciplines. This is providing the College of Optics and Photonics many opportunities to team with colleagues in such diverse disciplines as human factor psychology, materials science and engineering, bio-molecular sciences, information technology, simulation and modeling, digital media, etc.

In summary, the College of Optics and Photonics/CREOL has been an important seed in the growth of UCF. As UCF matures and grows, new opportunities are presented for optics. The Central Florida region has recognized the economic benefit of a top-tiered research university blossoming in its midst. UCF and the region are poised to be major players in this, the century of the photon! 
TABLE 1. Chronology of Hiring College of Optics and Photonics Faculty

\section{College of Optics \& Photonics: CREOL \& FPCE Faculty}

\begin{tabular}{|c|c|c|c|}
\hline Faculty Member & Position & Date of Hire & Comments \\
\hline Soileau, MJ & $\begin{array}{l}\text { VP Office of Research } \\
\text { and } \\
\text { Commercialization, } \\
\text { Professor of ECE \& } \\
\text { Physics }\end{array}$ & $12 / 1986$ & $\begin{array}{l}\text { First Director of } \\
\text { CREOL and } \\
\text { School of Optics }\end{array}$ \\
\hline Lin, Jui-Teng & $\begin{array}{l}\text { Associate Professor } \\
\text { of Physics }\end{array}$ & 01/1987 & $\begin{array}{l}\text { Left to start a } \\
\text { company }\end{array}$ \\
\hline Van Stryland, Eric & $\begin{array}{l}\text { Dean and Director, } \\
\text { Professor of Optics, } \\
\text { Physics \& ECE }\end{array}$ & 03/1987 & $\begin{array}{l}\text { Second Director } \\
\text { of the School of } \\
\text { Optics/CREOL }\end{array}$ \\
\hline Hagan, David & $\begin{array}{l}\text { Assoc Dean of } \\
\text { Academic Programs } \\
\text { \& Professor of Optics, } \\
\text { Physics \& ECE }\end{array}$ & 05/1987 & \\
\hline Bass, Michael & $\begin{array}{l}\text { Emeritus Professor of } \\
\text { Optics, Physics \& } \\
\text { ECE }\end{array}$ & 11/1987 & $\begin{array}{l}\text { Hired as VP for } \\
\text { Research in } 1987\end{array}$ \\
\hline Guenther, Karl & $\begin{array}{l}\text { Associate Professor } \\
\text { of ECE \& Physics }\end{array}$ & $12 / 1987$ & Deceased \\
\hline $\begin{array}{l}\text { Moharam, } \\
\text { Mohamed "Jim" }\end{array}$ & $\begin{array}{l}\text { Professor of Optics \& } \\
\text { ECE }\end{array}$ & $12 / 1987$ & \\
\hline Elias, Luis & $\begin{array}{l}\text { Professor of Optics \& } \\
\text { Physics }\end{array}$ & 06/1988 & Retired \\
\hline Kim, Jin & $\begin{array}{l}\text { Professor of Physics } \\
\& \text { ECE }\end{array}$ & 06/1988 & $\begin{array}{l}\text { Left for a position } \\
\text { in Korea }\end{array}$ \\
\hline Chai, Bruce & $\begin{array}{l}\text { Professor of Optics } \\
\text { Physics \& MMAE \& } \\
\text { ECE }\end{array}$ & $01 / 1989$ & $\begin{array}{l}\text { Left to start a } \\
\text { company }\end{array}$ \\
\hline Miller, Alan & $\begin{array}{l}\text { Professor of Physics } \\
\& \text { ECE }\end{array}$ & 01/1989. & $\begin{array}{l}\text { Left for position at } \\
\text { St. Andrews, } \\
\text { Scotland }\end{array}$ \\
\hline Li Kam Wa, Patrick & $\begin{array}{l}\text { Associate Professor } \\
\text { of Optics \& ECE }\end{array}$ & 09/1989 & \\
\hline Dixon, George & $\begin{array}{l}\text { Assistant Professor of } \\
\text { ECE }\end{array}$ & $12 / 1989$ & $\begin{array}{l}\text { Left to pursue } \\
\text { other } \\
\text { opportunities }\end{array}$ \\
\hline Silfvast, William & $\begin{array}{l}\text { Emeritus Professor of } \\
\text { Optics }\end{array}$ & $01 / 1990$ & \\
\hline Richardson, Martin & $\begin{array}{l}\text { Professor of Optics, } \\
\text { Physics \& ECE }\end{array}$ & 04/1990 & \\
\hline Stickley, Martin & $\begin{array}{l}\text { Assoc. Dir of } \\
\text { Industrial } \\
\text { Governmental Rel. \& } \\
\text { Sr. Research Scientist }\end{array}$ & 07/1990 & Retired \\
\hline Stegeman, George & Professor of Optics, & 07/1990 & \\
\hline
\end{tabular}




\begin{tabular}{|c|c|c|c|}
\hline & $\begin{array}{l}\text { Physics \& ECE, Cobb } \\
\text { Family Chair }\end{array}$ & & \\
\hline Boreman, Glenn & $\begin{array}{l}\text { Professor of Optics \& } \\
\text { ECE }\end{array}$ & 08/1990 & \\
\hline Harvey, James & $\begin{array}{l}\text { Associate Professor } \\
\text { of Optics \& ECE }\end{array}$ & 09/1990 & \\
\hline $\begin{array}{l}\text { Richardson, } \\
\text { Kathleen }\end{array}$ & $\begin{array}{l}\text { Associate Professor } \\
\text { of Optics Chemistry \& } \\
\text { MMAE }\end{array}$ & 08/1993 & $\begin{array}{l}\text { Left for a position } \\
\text { at Clemson } \\
\text { University }\end{array}$ \\
\hline Delfyett, Peter & $\begin{array}{l}\text { Professor of Optics \& } \\
\text { ECE }\end{array}$ & $12 / 1993$ & \\
\hline Kar, Aravinda & $\begin{array}{l}\text { Associate Professor } \\
\text { of Optics, MMAE \& } \\
\text { ECE }\end{array}$ & 03/1994 & \\
\hline Zel'dovich, Boris & $\begin{array}{l}\text { Professor of Optics \& } \\
\text { Physics }\end{array}$ & 08/1994 & \\
\hline Jenssen, Hans & Sr. Research Scientist & 09/1994 & Retired \\
\hline Riza, Nabeel & $\begin{array}{l}\text { Professor of Optics \& } \\
\text { ECE }\end{array}$ & 02/1995 & \\
\hline Glebov, Leon & Sr. Research Scientist & 09/1995 & \\
\hline Rolland, Jannick & $\begin{array}{lcc}\text { Assoc. } & \text { Professor } & \text { of } \\
\text { Optics, } & \text { ECE } & \& \\
\text { Computer Science } & \end{array}$ & 03/1996 & \\
\hline Dogariu, Aristide & $\begin{array}{l}\text { Associate Professor } \\
\text { of Optics }\end{array}$ & 08/1997 & \\
\hline Li, Guifang & $\begin{array}{l}\text { Professor of Optics, } \\
\text { Physics \& ECE }\end{array}$ & 09/1997 & \\
\hline Wolf, Emil & $\begin{array}{l}\text { Provost's } \\
\text { Distinguished } \\
\text { Research Professor }\end{array}$ & $01 / 1998$ & \\
\hline Johnson, Eric & $\begin{array}{l}\text { Associate Professor } \\
\text { of Optics }\end{array}$ & $01 / 2000$ & \\
\hline Siders, Craig & $\begin{array}{l}\text { Assistant Professor of } \\
\text { Optics }\end{array}$ & $08 / 2000$ & $\begin{array}{l}\text { Left to join } \\
\text { Livermore } \\
\text { National Lab }\end{array}$ \\
\hline Wu, Shin-Tson & $\begin{array}{l}\text { PREP Professor of } \\
\text { Optics }\end{array}$ & $07 / 2001$ & \\
\hline $\begin{array}{l}\text { Christodoulides, } \\
\text { Demetrios }\end{array}$ & $\begin{array}{l}\text { PREP Professor of } \\
\text { Optics }\end{array}$ & $08 / 2002$ & \\
\hline Kuebler, Stephen & $\begin{array}{l}\text { Assistant Professor of } \\
\text { Chemistry \& Optics }\end{array}$ & $08 / 2003$ & \\
\hline Kik, Pieter & $\begin{array}{l}\text { Assistant Professor of } \\
\text { Optics }\end{array}$ & $09 / 2003$ & \\
\hline Busch, Kurt & $\begin{array}{l}\text { Associate Professor } \\
\text { of Physics \& Optics }\end{array}$ & $12 / 2003$ & $\begin{array}{lll}\text { Returned to a } \\
\text { position } & & \text { in } \\
\text { Germany } & & \end{array}$ \\
\hline Schoenfeld, Winston & $\begin{array}{l}\text { Assistant Professor of } \\
\text { Optics }\end{array}$ & $05 / 2004$ & \\
\hline Deppe, Dennis & $\begin{array}{l}\text { Professor } \\
\text { Optics/FPCE } \\
\text { Chair }\end{array}$ & $06 / 2005$ & \\
\hline
\end{tabular}

